\title{
Stimulation of Sexual Reproduction of Phytophthora cactorum by Phospholipids
}

\author{
By W. H. KO \\ Department of Plant Pathology, University of Hawaii, Beaumont Agricultural Research Center, \\ Hilo, Hawaii 96720, USA
}

(Received 24 April 1985; revised 12 June 1985)

In a chemically defined liquid medium, soybean lecithins $(99 \%$ pure) were much more effective than $\beta$-sitosterol and cholesterol in stimulating oospore formation by isolate Pct $\mathrm{N}$ of Phytophthora cactorum at 20 and $24{ }^{\circ} \mathrm{C}$. Assuming that the $1 \%$ impurity is all sterols, such sterol impurity would account for less than $2 \%$ of the oospores produced in the presence of lecithins. Lecithins were also stimulatory to sexual reproduction of Phytophthora capsici and Pythium aphanidermatum but not Pythium vexans, whereas sterols were stimulatory to sexual reproduction of Pythium aphanidermatum and Pythium vexans but not Phytophthora capsici. Lecithins from soybean were more effective in inducing sexual reproduction by isolate $121 \mathrm{~F}$ of Phytophthora cactorum than were those from egg yolk. L- $\alpha$-Phosphatidylethanolamine from soybean was as effective as lecithins in inducing sexual reproduction, whereas $L-\alpha$-phosphatidylinositol from soybean and $L-\alpha$-phosphatidyl-L-serine from bovine brain were ineffective. Of four synthetic lecithins tested, only dioleoyl-L- $\alpha$-phosphatidylcholine was active. The triglycerides and fatty acids tested were inactive. The results suggest that the activity of lecithins is determined by the type and position of fatty acids in the molecular structures.

\section{INTRODUCTION}

Since 1964 when scientists from four different institutes (Elliott et al., 1964; Harnish et al., 1964; Hendrix, 1964; Leal et al., 1964) independently reported observations that addition of sterols to basal agar media induced sexual reproduction of both self-inducing and cross-inducing species of Phytophthora, the alleged essentiality of sterols for sexual reproduction of Phytophthora has been cited frequently as factual (Smith \& Berry, 1974; Barnett, 1976; Webster, 1980). Their reports have spurred research activity in this field with Phytophthora cactorum as the most commonly used test organism (Hendrix, 1970; Elliott, 1983). Recently, Ko \& Ho (1983) reported that sterols stimulate, but are not essential for, sexual reproduction of $P$. cactorum and Phytophthora parasitica because such a stimulatory effect can also be produced by lecithins. I report here new evidence for the role of lecithins in sexual reproduction of $P$. cactorum and the structural requirement for lecithins to stimulate sexual reproduction.

\section{METHODS}

Organisms. Isolates $121 \mathrm{~F}$ and Pct $\mathrm{N}$ of Phytophthora cactorum were supplied by D. L. McIntosh (Canadian Department of Agriculture, Summerland, BC, Canada) and W. D. Nes (USDA, Berkeley, Calif., USA) respectively. The $\mathrm{A}^{1}$ mating type of Phytophthora capsici is a sexual variant originating from aged culture of the $\mathrm{A}^{2}$ mating type (isolate P287) supplied by M. Aragaki (Ko, 1981) who also supplied isolates 606 of Pythium aphanidermatum and 530 of Pythium vexans.

Media. The basal medium contained the following: $\mathrm{KNO}_{3}, 0 \cdot 1 \mathrm{~g} ; \mathrm{KH}_{2} \mathrm{PO}_{4}, 0 \cdot 1 \mathrm{~g} ; \mathrm{MgSO}_{4} .7 \mathrm{H}_{2} \mathrm{O}, 0.05 \mathrm{~g}$; $\mathrm{CaCO}_{3}, 0 \cdot 1 \mathrm{~g}$; trace elements, $10 \mathrm{ml}$; asparagine, $0.1 \mathrm{~g}$; glucose, $2 \mathrm{~g}$; and distilled water, $1 \mathrm{l}$. The following trace elements were supplied per litre: FeEDTA, $100 \mathrm{mg}: \mathrm{CuSO}_{4} .4 \mathrm{H}_{2} \mathrm{O}, 10 \mathrm{mg} ; \mathrm{NaMoO}_{4} .2 \mathrm{H}_{2} \mathrm{O}, 5 \mathrm{mg}$; $\mathrm{Na}_{2} \mathrm{~B}_{4} \mathrm{O}_{7} .10 \mathrm{H}_{2} \mathrm{O}, 10 \mathrm{mg} ; \mathrm{ZnSO}_{4} .7 \mathrm{H}_{2} \mathrm{O}, 10 \mathrm{mg}$; thiamine hydrochloride, $100 \mathrm{mg}$. The basal medium was adjusted to $\mathrm{pH} 8$ with $0.5 \mathrm{M}-\mathrm{KOH}$ before the addition of other compounds. Cholesterol and $\beta$-sitosterol were 
obtained from Calbiochem and ICN, respectively. Phospholipids, triglycerides and fatty acids were purchased from Sigma. These compounds were dissolved in ether individually $\left(10 \mathrm{mg} \mathrm{m}^{-1}\right)$ before being added to the basal medium. Those phospholipids in chloroform or hexane were evaporated to dryness at $24^{\circ} \mathrm{C}$ in a $50 \mathrm{ml}$ beaker in a fume hood, and then dissolved in ether. Before use, $200 \mathrm{ml}$ ether was washed twice with $400 \mathrm{ml}$ distilled water by shaking in a $1000 \mathrm{ml}$ separation funnel. Those media containing large particles of insoluble compounds were ground in a tissue homogenizer before sterilization. Flasks $(250 \mathrm{ml})$ each containing $10 \mathrm{ml}$ medium were covered with aluminium foil and autoclaved for $15 \mathrm{~min}$. Highly purified Seakem agarose (HGT-P Agarose; Marine Colloids) which was essentially free of nutrient contaminants (Ho \& Ko, 1980; Ko \& Ho, 1983) was used to solidify the basal medium at a concentration of $0.8 \%(w / v)$.

Oospore production. A piece of agar culture (approx. $5 \times 5 \times 3 \mathrm{~mm}$ ) from each fungus growing on $10 \% \mathrm{~V}-8$ agar $\left[10 \%(\mathrm{v} / \mathrm{v}) \mathrm{V}-8\right.$ vegetable juice, $0.02 \%(\mathrm{w} / \mathrm{v}) \mathrm{CaCO}_{3}$ and $2 \%(\mathrm{w} / \mathrm{v})$ Bacto-agar] was placed on the centre of a basal agarose medium in a Petri plate. After incubation at $24{ }^{\circ} \mathrm{C}$ for $4 \mathrm{~d}$, pieces of culture (approx. $3 \times 3 \times 3 \mathrm{~mm}$ ) obtained more than $10 \mathrm{~mm}$ from the inoculum were used to inoculate the media. For $P$. capsici, each flask of medium was inoculated with two pieces each of $\mathrm{A}^{1}$ and $\mathrm{A}^{2}$ mating type cultures. For the other species, each flask of medium was inoculated with one piece of culture. After incubation at $24^{\circ} \mathrm{C}$ in darkness for $10 \mathrm{~d}, 40 \mathrm{ml}$ distilled water was added to each flask and the culture was triturated in an Omni mixer at 4500 r.p.m. for 1 min. The suspension was mixed with 2 drops (approx. $50 \mu \mathrm{l} \mathrm{each)} \mathrm{of} 5 \%(\mathrm{v} / \mathrm{v})$ Tween 80 and the oospore concentration in the suspension was determined by counting the number of spores in 1,10 or $100 \mu$ with a Pipetman microlitre pipette (P-20D or P200D; West Coast Scientific, Oakland, Calif., USA; Ko et al., 1973). Two replicates were used for each treatment and all experiments were repeated at least twice.

\section{RESULTS AND DISCUSSION}

Lecithins at $1000 \mu \mathrm{g} \mathrm{ml}^{-1}$ induced formation of 15667 oospores of $P$. cactorum isolate Pct $\mathrm{N}$ per $\mathrm{ml}$ of medium at $20^{\circ} \mathrm{C}$, whereas $\beta$-sitosterol and cholesterol at $10 \mu \mathrm{g} \mathrm{ml}^{-1}$ induced formation of only 206 and 275 oospores per ml of medium, respectively (Table 1 ). At $24^{\circ} \mathrm{C}$, the amounts of oospores induced by lecithins, $\beta$-sitosterol and cholesterol were 4667, 25 and 90 per $\mathrm{ml}$ of medium, respectively.

Since $\beta$-sitosterol is the common sterol in soybean (Windholz, 1976) and is one of the most active sterols (with an optimum concentration of about $10 \mu \mathrm{g} \mathrm{ml}^{-1}$ ) in inducing sexual reproduction of $P$. cactorum (Elliott, 1972; Elliott et al., 1966), these results suggest that lecithins were much more effective than sterols in stimulating oospore formation by isolate Pct $\mathrm{N}$ of $P$. cactorum. Although the lecithins used were only $99 \%$ pure, the possibility that a sterol present as an impurity in the lecithins is responsible for the stimulatory effect rather than the lecithins per $s e$ is unlikely. Even if the $1 \%$ impurity in the soybean lecithins is entirely sterols, such sterol impurity would account for less than $2 \%$ of the oospores produced by $P$. cactorum in the presence of lecithins.

The stimulatory spectrum of lecithins was different from that of sterols (Table 2). Lecithins were stimulatory to sexual reproduction of $P$. capsici and Pythium aphanidermatum but not Pythium vexans, whereas sterols were stimulatory to Pythium aphanidermatum and Pythium vexans but not $P$. capsici. This suggests that the mode of action of lecithins in inducing sexual reproduction in fungi is different from that of sterols. Sterols have also been considered to be essential for sexual reproduction of Pythium species including Pythium aphanidermatum (Hendrix, 1965, 1970; Elliott, 1983). This result shows that the stimulatory effect of sterols on sexual reproduction of Pythium aphanidermatum can also be produced by lecithins. Therefore, as with Phytophthora, sterols are stimulatory to, but not essential for, sexual reproduction of Pythium aphanidermatum. Sexual reproduction of Pythium vexans was induced by sterols but not lecithins. However, whether sterols are essential for sexual reproduction in this fungus is not known because other substances have not been tested.

Since isolate $121 \mathrm{~F}$ of $P$. cactorum produced many more oospores in the presence of lecithins than isolate Pct $\mathrm{N}$ (Ko \& Ho, 1983), the former was used in the determination of the structural requirement for lecithins to stimulate sexual reproduction. Lecithins obtained from soybean were more effective than those obtained from egg yolk in inducing oospore formation by isolate $121 \mathrm{~F}$ of $P$. cactorum (Table 3). When the concentration of soybean lecithins was decreased from 1000 to 100 and $10 \mu \mathrm{g} \mathrm{ml}^{-1}$, the number of oospores produced per ml of medium decreased from 59000 to 663 and 0, respectively. This may explain why Elliot et al. (1966) did not find lecithins 
Table 1. Oospore formation by isolate Pct $N$ of Phytophthora cactorum in a defined liquid medium containing $1000 \mu \mathrm{g}$ lecithins $\mathrm{ml}^{-1}$ or $10 \mu \mathrm{g}$ sterols $\mathrm{ml}^{-1}$ at 20 and $24^{\circ} \mathrm{C}$

No. of oospores per $\mathrm{ml}$ of medium at:

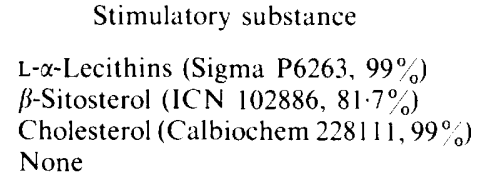

Stimulatory substance

None

\begin{tabular}{|c|c|}
\hline $20^{\circ} \mathrm{C}$ & $24^{\circ} \mathrm{C}$ \\
\hline 15667 & 4667 \\
\hline 206 & 25 \\
\hline 275 & 90 \\
\hline 0 & 0 \\
\hline
\end{tabular}

Table 2. Oospore formation by species of Phytophthora and Pythium in a defined liquid medium containing $1000 \mu \mathrm{g}$ lecithins $\mathrm{ml}^{-1}$ or $10 \mu \mathrm{g}$ sterols $\mathrm{ml}^{-1}$ at $24^{\circ} \mathrm{C}$

\begin{tabular}{|c|c|c|c|}
\hline \multirow[b]{2}{*}{$\begin{array}{l}\text { Stimulatory } \\
\text { substance* }\end{array}$} & \multicolumn{3}{|c|}{$\begin{array}{l}\text { No. of oospores } \\
\text { per ml of medium }\end{array}$} \\
\hline & $\begin{array}{l}\text { Phytophthora } \\
\text { capsici† }\end{array}$ & $\begin{array}{c}\text { Plthium } \\
\text { aphanidermatum }\end{array}$ & $\begin{array}{l}\text { Pythium } \\
\text { texans }\end{array}$ \\
\hline L- $\alpha$-Lecithins & 221 & 67417 & 0 \\
\hline$\beta$-Sitosterol & 0 & 13050 & 10360 \\
\hline Cholesterol & 0 & 12760 & 14500 \\
\hline None & 0 & 0 & 0 \\
\hline
\end{tabular}

Table 3. Oospore formation by isolate $121 \mathrm{~F}$ of Phytophthora cactorum in a defined liquid medium containing $1000 \mu \mathrm{g} \mathrm{ml} l^{-1}$ of various phospholipids at $24^{\circ} \mathrm{C}$

\section{Phospholipid}

Different sources of $L-\alpha$-lecithins

Soybean, type III-S (Sigma P6263, 99\%)

Egg yolk, type III-E (Sigma P5388, 99\%)

Egg yolk, type V-EA (Sigma P5763, 99\%)

Other types of phospholipids

L- $\alpha$-Phosphatidylethanolamine (Sigma P5274, soybean, 98\%)

L- $\alpha$-Phosphatidylinositol (Sigma P5766, soybean, 98\%)

L- $\alpha$-Phosphatidyl-L-serine (Sigma P7769, bovine brain, 98\%)

Synthetic lecithins

Dioleoyl-L- $\alpha$-phosphatidylcholine

Dipalmitoyl-L- $\alpha$-phosphatidylcholine

Dilinoleoyl-L- $\alpha$-phosphatidylcholine

Distearoyl-L- $\alpha$-phosphatidylcholine

None
No. of oospores per $\mathrm{ml}$ of medium

stimulatory to sexual reproduction of $P$. cactorum as they used $10 \mu \mathrm{g}$ lecithins $\mathrm{ml}^{-1}$. Of the three other types of phospholipids tested, only $L-\alpha$-phosphatidylethanolamine (cephalin) from soybean was effective in inducing oospore formation of P. cactorum (Table 3). Neither L- $\alpha$-phosphatidylinositol from soybean nor $\mathrm{L}-\alpha$-phosphatidyl-L-serine from bovine brain was effective. Their ineffectiveness was not due to the presence of inositol or serine because addition of $200 \mu \mathrm{g}$ myo-inositol ml-1 or $100 \mu \mathrm{g} \mathrm{L}$-serine $\mathrm{ml}^{-1}$ to basal medium plus $1000 \mu \mathrm{g} \mathrm{ml}^{-1}$ of soybean lecithins did not reduce the number of oospores produced by P. cactorum. About 67000 and 80000 oospores per $\mathrm{ml}$ of medium were produced in the presence of myo-inositol and L-serine, respectively. Of the four synthetic lecithins tested only dioleoyl-L- $\alpha$-phosphatidylcholine was effective in inducing sexual reproduction of $P$. cactorum (Table 3). Dipalmitoyl-, dilinoleoyl-and 
distearoyl-L- $\alpha$-phosphatidylcholines were ineffective. P. cactorum did not form oospores in basal medium plus $100 \mu \mathrm{g} \mathrm{K}_{2} \mathrm{HPO}_{4} \mathrm{ml}^{-1}, 100 \mu \mathrm{g}$ choline chloride $\mathrm{ml}^{-1}$ and $1000 \mu \mathrm{g} \mathrm{ml}^{-1}$ of individual triglycerides including triolein, tripalmitin, trilinolein, trilinolenin and tristearin. The fungus also failed to form oospores when triglycerides in the above media were replaced by $100 \mu \mathrm{g}$ glycerol $\mathrm{ml}^{-1}$ and $1000 \mu \mathrm{g} \mathrm{ml}^{-1}$ of their corresponding fatty acids.

Since L- $\alpha$-phosphatidylethanolamine was as effective as lecithins in inducing sexual reproduction of $P$. cactorum, the choline component was not associated with the activity of lecithin. The activity is probably determined by the type and position of fatty acids in the molecular structure of lecithin because lecithins from egg yolk were not as active as lecithins from soybean. Moreover, of the four different kinds of synthetic lecithins tested, only the lecithin containing oleic acid was effective. Those lecithins containing other types of fatty acids were ineffective. Since dioleoyl-L- $\alpha$-phosphatidylcholine was about one-tenth as active as soybean lecithins, the type and position of the fatty acids in the molecular structures of the lecithins which are most effective for sexual reproduction of $P$. cactorum remain to be determined. Results from this study also showed that the activity of lecithins probably cannot be replaced by triglycerides or fatty acids.

Lecithins have been reported by Hohl (1975) to be stimulatory to vegetative growth of several species of Phytophthora including P. cactorum. Synthetic lecithins were also ineffective or less effective than natural lecithins in promoting growth of $P$. cactorum. However, contrary to sexual reproduction, the growth promoting activity of lecithins in $P$. cactorum was totally replaced by linoleic acid.

\section{REFERENCES}

BARNETT, J. H. (1976). Fundamentals of Micology. New York: Crane Russak \& Co.

Elliott, C. G. (1972). Sterols and the production of oospores by Phytophthora cactorum. Journal of General Microbiology 72, 321-327.

Elliott, C. G. (1983). Physiology of sexual reproduction in Phytophthora. In Phytophthora: Its Biology, Ecology and Pathology. Edited by D. C. Erwin, S. Bartnicki-Garcia \& P. H. Tsao. St Paul, Minnesota: American Phytopathological Society.

Elliott, C. G., Hendrie, M. R. \& KNights, B. A. (1966). The sterol requirement of Phytophthora cactorum. Journal of General Microhiolog. 42, 425435 .

Elliott, C. G., Hendrie, M. R., Knights, B. A. \& PARKER, W. (1964). A steroid growth factor requirement in a fungus. Nature, London 203, 427 428 .

Harnish, W. N., Berg. L. A. \& Lilly, B. G. (1964). Factors in lima bean and hemp seed required for oospore formation by species of Phytophthora. Phy'topathology' 54, 895.

HENDRIX, J. W. (1964). Sterol induction of reproduction and stimulation of growth of Pythium and Phytophthora. Science 144, 10281029.

HENDRIX, J. W. (1965). Influence of sterols on growth and reproduction of $P$ ythium and Phytophthora spp. Phytopathology 55, 790-797.

HendRIX, J. W. (1970). Sterols in growth and reproduc-

tion of fungi. Annual Reriew of Phitopathology 8 , $111-130$.

Ho, W. C. \& Ko, W. H. (1980). Agarose medium for bioassay of antimicrobial substances. Phytopatho$\log _{1}$ 70, 764-766.

HOHL, H. R. (1975). Levels of nutritional complexity in Phytophthora: lipids, nitrogen sources and growth factors. Phytopathologische Zeitschrift 84, 18-33.

Ko, W. H. (1981). Reversible change of mating type in Phitophthora parasitica. Journal of General Microbiology 125, 451-454.

Ko, W. H. \& Ho, W. C. (1983). Reassessment of apparent sterol requirement for sexual reproduction in Phytophthora. Annals of the Phytopathological Society of Japan 49, 316-321.

Ko, W. H.. Chase, L. L. \& Kunimoto, R. K. (1973). A microsyringe method for determining concentration of fungal propagules. Phitopathology 63, 1206-1207.

Leal. J. A., Friend, J. \& Holliday, P. (1964). A factor controlling sexual reproduction in Phytophthora. Nature, London 203, 545-546.

SMITH, J. E. \& BERRY, D. R. (1974). An Introduction to Biochemistry of Fungal Derelopment. New York: Academic Press.

Webster, J. (1980). Introduction to Fungi. London: Cambridge University Press.

Windholz, M. (1976). The Merck Index, 9th edn. Rahway, New Jersey: Merck \& Co., Inc. 